\author{
Ks. Tadeusz Pabjan* \\ UPJPII w Krakowie Wydziat Teologiczny Sekcja w Tarnowie
}

\title{
POSTULATY NAUK PRZYRODNICZYCH POD ADRESEM TEOLOGII STWORZENIA
}

W sensie ścisłym nauki przyrodnicze nie mają żadnych „postulatów pod adresem teologii”. Wynika to z samej natury tych nauk i z ich metodologicznej odrębności. Poza tym, spora część fizyków, chemików, biologów itd. to ludzie niewierzący, dla których teologia nie jest żadną nauką, a w każdym razie nie jest nauką, w stosunku do której można byłoby formułować jakiekolwiek postulaty. Ale jest również spora grupa uczonych - przedstawicieli nauk przyrodniczych - którzy wierzą w Boga i traktują poważnie teologię. Jeśli więc można mówić o postulatach nauk przyrodniczych pod adresem teologii (w tym przypadku teologii stworzenia), to właśnie w takim sensie: będą to postulaty formułowane przez tę „wierzącą część" fizyków, chemików, biologów itd., którzy w uprawianych przez siebie dyscyplinach naukowych dostrzegają czy odnajdują problemy i kwestie, które z pewnych względów są ważne dla teologii. Można na to samo zagadnienie spojrzeć jeszcze inaczej: my sami - którzy zajmujemy się teologią - patrzymy na nasze teologiczne problemy przez pryzmat współczesnych teorii naukowych formułowanych $\mathrm{w}$ ramach nauk przyrodniczych. I staramy się wyłowić te kwestie, które mogą być dla nas - teologów - z pewnych względów istotne.

Pierwszy postulat - podstawowy, zasadniczy i w pewnym sensie oczywisty (choć okazuje się, że dla wielu wcale nie jest on oczywisty) - jest taki, że teologia w ogólności, a teologia stworzenia w szczególności, powinna zainteresować się tym, co nauka ma do powiedzenia na temat np. początku Wszechświata, ewolucji życia, ewolucji człowieka, struktury materii itd. Dlaczego tak? Z jakiego powodu teologia ma się interesować naukami przy-

* Ks. Tadeusz Pabjan, doktor habilitowany nauk humanistycznych w zakresie filozofii, kierownik katedry filozofii na Wydziale Teologicznym Sekcja w Tarnowie UPJPII w Krakowie, członek Ośrodka Badań Interdyscyplinarnych przy UPJPII w Krakowie, sekretarz czasopisma „Zagadnienia Filozoficzne w Nauce”, członek Centrum Kopernika Badań Interdyscyplinarnych w Krakowie, redaktor strony internetowej Wydziału Teologicznego Sekcja w Tarnowie UPJPII w Krakowie, wykładowca przedmiotów filozoficznych (filozofia przyrody, ogólna metodologia nauk, historia filozofii, wstęp do filozofii) na Wydziale Teologicznym Sekcja w Tarnowie UPJPII w Krakowie. 
rodniczymi - a nie odwrotnie? Można usłyszeć czasami takie pytanie, a właściwie to zarzut formułowany przez teologów: Dlaczego to my mamy się interesować fizyką i biologią? Niech fizycy i biolodzy zainteresują się teologią! Otóż relacja pomiędzy teologią i naukami przyrodniczymi nie jest symetryczna - w tym sensie, że nauki przyrodnicze można bez teologii z powodzeniem uprawiać, natomiast teologię bez nauk przyrodniczych można uprawiać, ale tylko do pewnego stopnia. Za słusznością tego wniosku przemawiają co najmniej trzy argumenty.

Przede wszystkim teologia musi z oczywistych względów odwoływać się do obrazu świata - np. wtedy, gdy mówi o stworzeniu - a obraz świata budowany jest $\mathrm{z}$ informacji, które otrzymujemy właśnie $\mathrm{z}$ nauk przyrodniczych. Teologia oczywiście może nie chcieć korzystać z tych informacji, wychodząc z założenia, że jej własne metody (np. metody interpretacji Pisma Świętego) wystarczają do zbudowania takiego obrazu. Ale historia pokazuje, że takie postawienie sprawy zawsze kończyło się źle dla teologii (i pośrednio dla całego Kościoła). Wystarczy przywołać sprawę Galileusza, gdy Kościół postawił na szali cały swój teologiczny autorytet, opowiadając się za geocentryzmem (za tym, że Ziemia jest nieruchoma i że znajduje się w centrum wszechświata) i potępiając heliocentryzm.

Drugi argument związany jest z tym, że teologia nie jest „sztuką dla sztuki”, ale ma za zadanie przybliżać prawdy wiary (czy też twierdzenia teologiczne) współczesnemu człowiekowi. A światopogląd współczesnego człowieka - czy tego chcemy czy nie - jest światopoglądem naukowym albo przynajmniej popularnonaukowym. To jest światopogląd budowany $\mathrm{z}$ tych informacji o świecie, które pochodzą z teorii współczesnej nauki. Nośnikiem tych informacji jest telewizja, Internet, prasa, radio itp.

I właśnie dlatego prawy wiary (np. prawda o stworzeniu człowieka) muszą się jakoś w ten światopogląd wpisywać, muszą ten światopogląd uwzględniać. Była kiedyś popularna tzw. teoria dwóch prawd, która mówiła, że to samo twierdzenie może być jednocześnie prawdziwe w nauce i fałszywe w teologii lub odwrotnie. Ale takiej teorii na dłuższą metę nie da się utrzymać - przede wszystkim dlatego, że człowiek jest psychofizyczną jednością i żyje w jednym świecie, który nie jest podzielony na sferę religijną i sferę naukową. I dlatego ludzie wierzący muszą mieć spójny światopogląd, w którym prawdy religijne (np. prawda o stworzeniu człowieka) nie są sprzeczne z prawdami naukowymi.

Żeby jednak teologia mogła współczesnemu człowiekowi zaproponować takie sformułowanie czy też taką interpretację prawd wiary, którą ten będzie mógł włączyć do swojego naukowego światopoglądu, to oczywiście najpierw sama teologia musi sformułowanie tych prawd wiary zweryfikować i porównać z tym, co ma do powiedzenia nauka. Ale żeby móc zweryfikować i porównać, trzeba najpierw poznać to, co nauka ma do powiedzenia np. o początku świata i pochodzeniu człowieka. 
Oczywiście można sobie wyobrazić taką sytuację, w której teologowie uznają, że to nie jest ich problem, że ich zadaniem jest formułowanie dogmatów i wypowiadanie $\mathrm{w}$ języku teologicznym prawd wiary, natomiast odbiorca tego przekazu - współczesny człowiek - powinien sobie sam poradzić $\mathrm{z}$ włączeniem tych prawd w swój naukowy światopogląd. Wydaje się jednak, że takie podejście jest ze wszech miar niewłaściwe, bo w rzeczywistości sprowadza się ono do przerzucania odpowiedzialności na odbiorców przekazu teologicznego, którzy często sami nie są zdolni, by reinterpretować prawdy wiary i uzgadniać je $\mathrm{z}$ teoriami naukowymi.

Nic dziwnego, że wielu z tych, którzy dzisiaj porzucają wiarę, którzy odchodzą z Kościoła, to często ludzie, którzy np. na katechezie albo na kazaniu słyszeli o tym, że Bóg stworzył wszystkie gatunki roślin i zwierząt w gotowej postaci, a potem np. na studiach poznają teorię ewolucji, zgodnie z którą życie pojawiło się na Ziemi na drodze ciągle zachodzących przeobrażeń. I ponieważ nie potrafią sami dokonać reinterpretacji prawdy o stworzeniu, uznają, że ta prawda nie jest prawdą. I przestają wierzyć w Boga.

Trzeci argument przemawiający za tym, że teologia powinna poznawać wyniki nauk szczegółowych, odwołuje się do znanej reguły interpretacyjnej sformułowanej przez św. Augustyna w V wieku po Chrystusie. Reguła ta dotyczy lektury Pisma Świętego i głosi, że jeśli gdziekolwiek pojawia się sprzeczność pomiędzy dosłownym rozumieniem tekstu biblijnego i „dobrze ustaloną prawdą rozumu", to należy w takim przypadku szukać metaforycznego sensu tego fragmentu Biblii. Co to znaczy ,,dobrze ustalona prawda rozumu"? Otóż to są właśnie przede wszystkim dobrze uzasadnione prawdy naukowe. Jeśli chodzi o teologię stworzenia, to takimi „dobrze ustalonymi prawdami rozumu" jest np. to, co mówi teoria ewolucji: że ciało człowieka powstało w wyniku długotrwałego procesu zmian biologicznych; albo kosmologia relatywistyczna, która mówi, że obecny Wszechświat jest końcowym etapem trwającej 13,7 miliarda lat ewolucji kosmicznej.

Zgodnie ze wspomnianą wcześniej regułą, jeśli te prawdy są sprzeczne $\mathrm{z}$ dosłownym rozumieniem biblijnego opisu stworzenia, to trzeba szukać jego metaforycznego sensu. Żeby jednak móc stwierdzić, czy to rzeczywiście jest sprzeczne czy nie jest sprzeczne $\mathrm{z}$ dosłownym rozumieniem Biblii, to trzeba najpierw wiedzieć, co głosi ta „dobrze ustalona czy potwierdzona prawda rozumu", czyli - innymi słowy - trzeba wiedzieć, co mówi na dany temat nauka.

Warto w tym miejscu przywołać uzasadnienie, które podaje św. Augustyn dlaczego należy stosować tę jego metodę interpretacyjną. Biskup Hippony mówi, że ten, kto jej nie stosuje, naraża swoją wiarę na ośmieszenie w oczach pogan. Nietrudno zauważyć, że to spostrzeżenie Augustyna jest wyjątkowo aktualne również i dzisiaj: jeśli mamy dobrze potwierdzoną prawdę naukową (np. o tym, że życie pojawiło się na drodze ewolucji), i jeśli ktoś odrzuca tę prawdę, opowiadając się za dosłownym rozumieniem tekstu biblijnego o stworzeniu człowieka, to taki ktoś ośmiesza swoją wiarę 
w oczach współczesnych pogan, to znaczy ateistów. Kościół wielokrotnie w przeszłości popełniał taki błąd, że obstawał przy dosłownym rozumieniu tekstu Biblii, kwestionując okrycia i teorie naukowe. I zawsze kończyło się to źle dla niego (np. sprawa Galileusza). Nie wolno zatem tego błędu dzisiaj po raz kolejny powtarzać.

Na koniec warto wymienić kilka propozycji, które mogłyby stać się takimi konkretnymi postulatami nauk przyrodniczych formułowanymi pod adresem teologii stworzenia. Są to pewne zagadnienia, które pojawiają się w naukach przyrodniczych, a które mogłyby - i powinny być podjęte przez teologię.

1) Problem początku Wszechświata. We współczesnej kosmologii mówi się o Wielkim Wybuchu jako o początku obecnej fazy ewolucji Wszechświata, ale nie jest wykluczone, że niebawem okaże się, iż przed Wielkim Wybuchem było „coś” innego - np. jakiś „,wcześniejszy" etap istnienia kosmosu. Warto byłoby w tym kontekście na nowo podjąć i poddać teologicznej analizie doktrynę św. Tomasza z Akwinu, który postulował odróżnienie początku świata od aktu stworzenia. $\mathrm{W}$ tej interpretacji Bóg stwarza świat istniejący odwiecznie.

2) To samo zagadnienie warto by podjąć i na nowo rozpatrzyć w kontekście doktryny creatio continua - aby ukazać stwórczy akt Boga i zarazem Jego nieustanne oddziaływanie na świat przyrody dokonujące się za pośrednictwem praw natury.

3) Problem pochodzenia życia i powstania ciała człowieka na drodze ewolucji. Tu jest oczywiście bardzo wiele nierozstrzygniętych zagadnień teologicznych, które warto byłoby poddać szczegółowej analizie - np. problem powstania (stworzenia) duszy ludzkiej: Kiedy to się stało? Czy w jednym momencie, czy stopniowo? Czy wszystkie organizmy otrzymały duszę jednocześnie, czy w zależności od tempa rozwoju psychicznego czy „duchowego” danego organizmu?

4) Inną nierozstrzygniętą trudnością $z$ tego samego zakresu jest problem grzechu pierwszych ludzi. Jeśli zgodnie z kreacjonizmem ewolucyjnym ciało człowieka powstało na drodze ewolucji, a dusza została przez Boga stworzona (skok ontologiczny), to jak należy rozumieć grzech pierworodny? 